\title{
METHODS OF AUTONOMOUS UNDERWATER VEHICLES POSITIONING
}

\section{Norbert Sigiel ${ }^{0}$}

13th MCM Squadron, Śmidowicza 48 Str., 81-106 Gdynia, Poland; e-mail: n.sigiel@ron.mil.pl, norbert.sigiel@gmail.com; ORCID ID 0000-0001-6184-1063

\begin{abstract}
Article presented below is a prelude to the process of autonomous underwater systems positioning. An article include description of positioning methods and guidelines for the operators of autonomous underwater vehicles (AUVs), concerning above mentioned process.
\end{abstract}

Key words:

autonomous underwater systems, sea bottom researches, positioning methods.

Research article

(C) 2019 Norbert Sigiel This is an open access article licensed under the Creative Commons Attribution-NonCommercial-NoDerivatives 4.0 license (http://creativecommons.org/licenses/by-nc-nd/4.0/) 


\section{INTRODUCTION}

Taking into account dynamic development of autonomous underwater systems nowadays we have new possibilities of detection, classification and identification objects on a sea bottom, object which sometimes cause real threat for shipping and maritime environment. Baltic Marine Environment Protect Commission (HELCOM) provide an information that only during the II World War around 40000 tons of chemical ammunition and weapon have been thrown into the water (fig. 1).

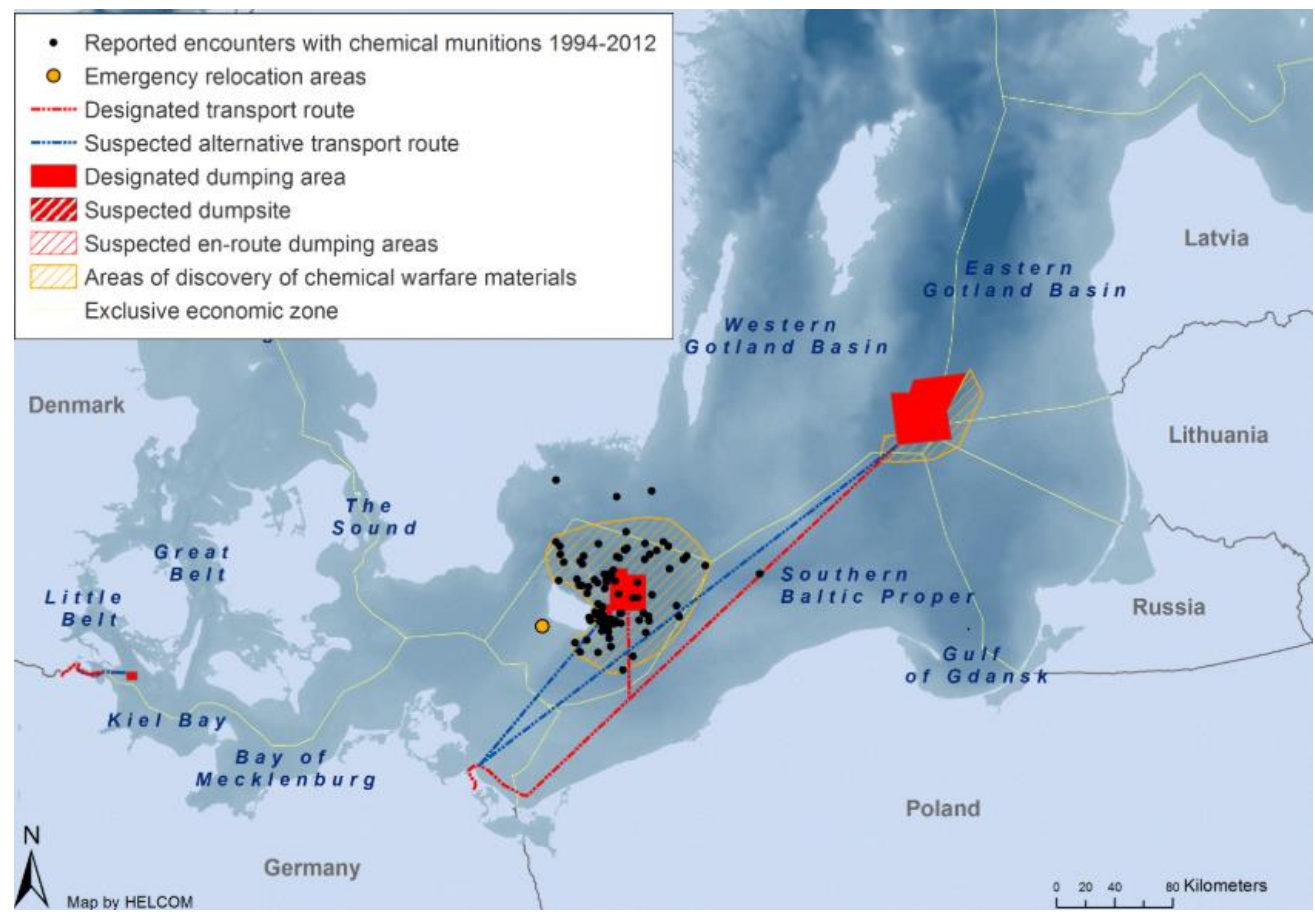

Fig. 1. Overview map of known and suspected dumpsites of chemical warfare materials in the Helsinki Convention Area [3]

Precise localization of above mentioned objects became a crucial factor for the further operation. Article presented below is a prelude to the process of autonomous underwater systems positioning. An article includes description of positioning methods and guidelines for the operators of autonomous underwater vehicles (AUVs). The aim of researches described in the paper is to present possibilities and restrictions concerning establishing AUVs position, mainly during the operations focused on 
detection, classification and identification of small objects (e.g. $1 \mathrm{~m} \times 1 \mathrm{~m}$ ). The following sections includes characteristics of positioning systems based on Global Positioning System (GPS) data, hydroacoustic systems with Long Base Line (LBL), Ultra Short Base Line (USBL) and their implementations.

\section{METHODS OF AUTONOMOUS UNDERWATER VEHICLES POSITIONING}

Whole methods of autonomous underwater vehicles positioning could be shared on methods concerning establishing vehicle movement parameters in space, based on implemented inside subsystems, like Inertial Navigation Systems (INSs), and methods which provide possibilities to establish position by calculations of ranges and bearings to external reference objects. In that case we can take into account the positioning systems with Long Base Line, Ultra Short Base Line and their implementations.

\section{Inertial Navigation Systems}

Inertial Navigations Systems are independent methods of providing vehicle position during the whole mission time, without external sources and systems. Based on data acquired from accelerometers, gyroscopes and other sensors vehicle processors are calculating precisely all changes of vehicle position in six degrees of freedom. Data distributed from aforementioned sensors like doppler velocity logs (DVLs), pressure sensors, altimeters, motion reference units (MRUs) give the possibility to reach highest confidence that calculated position is very accurate. The main disadvantage of INS is degradation of precision with the mission time. Fig. 2 shows degradation of INS accuracy with the AUV mission time. Removing the magnetic key start the AUV mission (Mission Time 06:00), from that point position accuracy have been downgrading and after three hours (Mission Time 09:00) reach accuracy of $14 \mathrm{~m}$. During this time vehicle has been using only INS to establish position. AUVs high position quality at 09:01 is the result of sending position updates by operator, via acoustic link. During autonomous underwater vehicle movement, error of determining heading is directly connected with position calculation. Nowadays, with the accurate INS, error of establishing heading equal 0,001 rad. cause errors of position equal to $0,1 \%$ of travelled distance. 


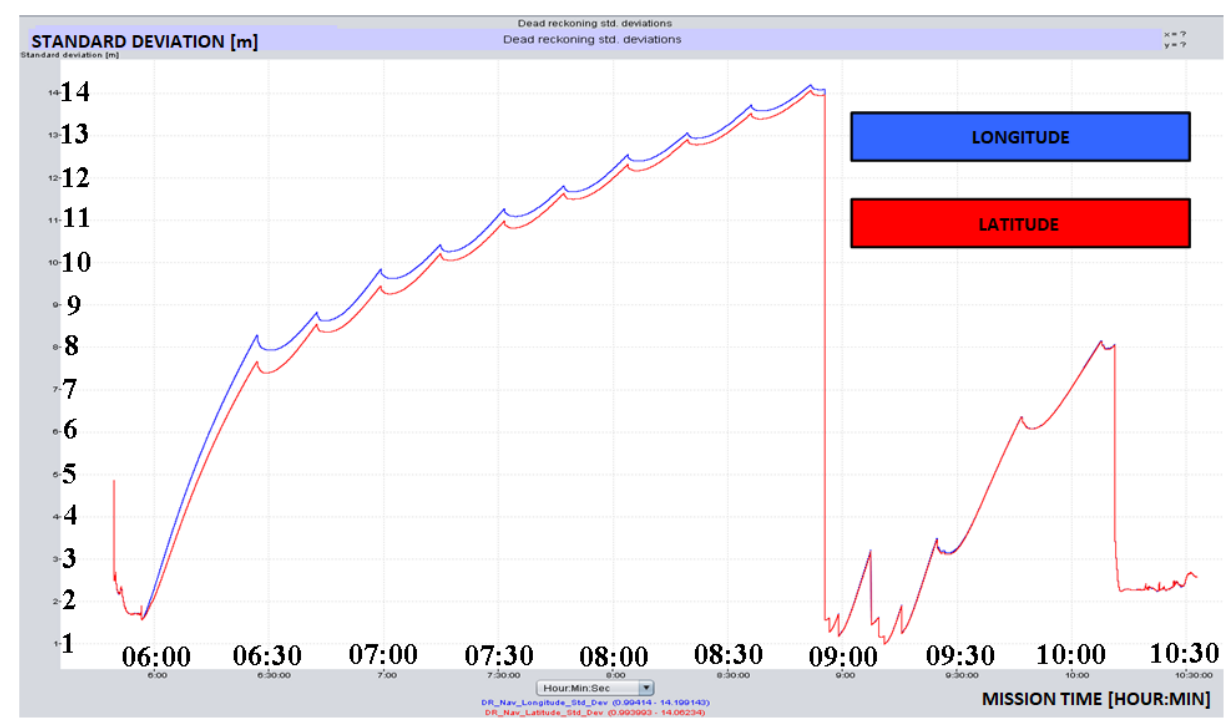

Fig. 2. Degradation of INS accuracy with the AUV mission time

\section{Vehicle positioning with Global Navigation Satellite System (GNSS) data}

Operations focused on detection, classification and identification of small objects (e.g. $1 \mathrm{~m} \times 1 \mathrm{~m}$ ) require high accuracy of collected data, mainly position. According to that fact the position calculated by INS during the mission needs to be periodically upgraded. One of the method to obtain high accuracy of vehicle position is based on data provided by GPS.

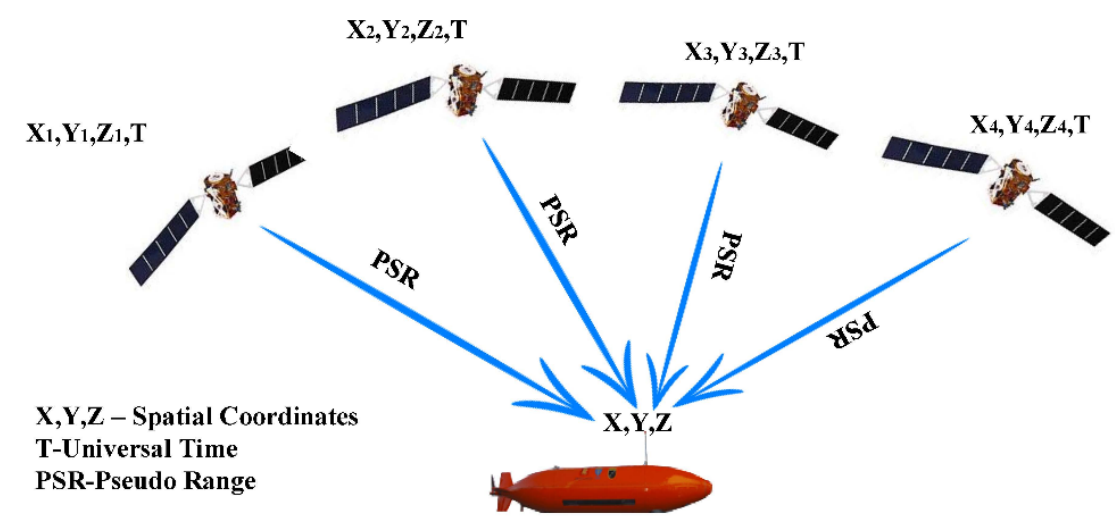

Fig. 3. Positioning of AUV based on information provided by GNSS;

clock signals from each satellite are compared with the clock in the vehicle to give pseudo range data from which the position is calculated [1] 
The process of AUV position calibration based on GNSS data require resurfacing vehicle and keeping that position for few minutes. According to that, construction of AUV, mainly concerning communication antennas, have to provide a stable communication with the elements of global satellite systems like GPS, GLONASS, GALILEO and also geostationary systems providing differential signals (e.g. WAAS, EGNOS) [4]. It is highly recommended for the operators to verify the proper ballasting of vehicle during preparations system for the mission. Even very high antenna won't help us to obtain GPS data below the surface.

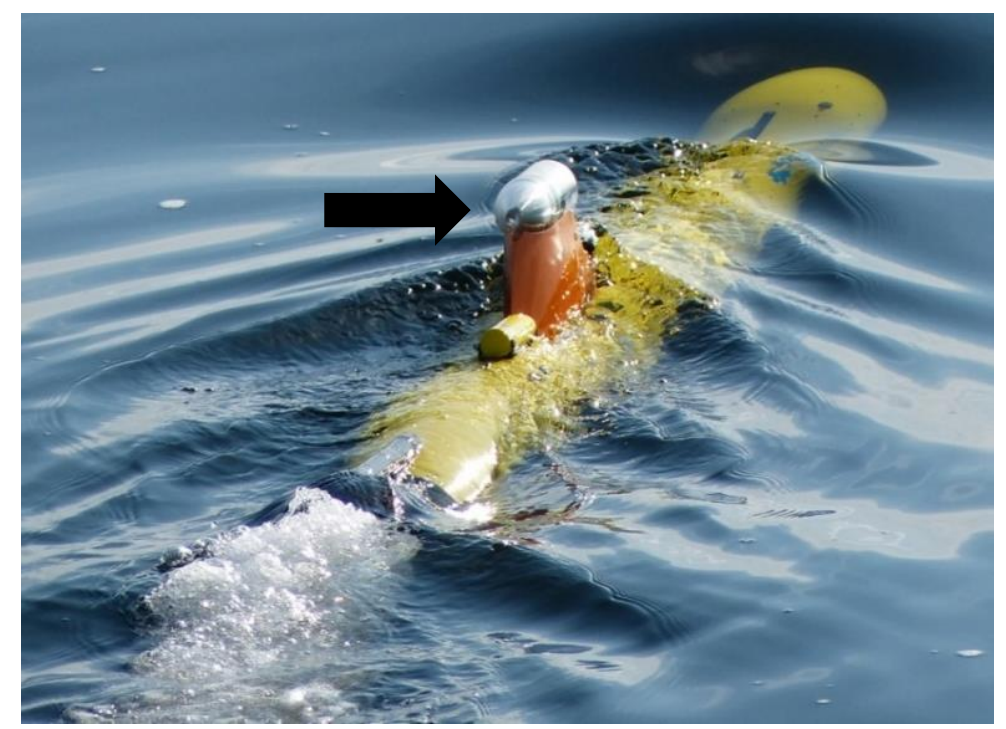

Fig. 4. Communication module of AUV GAVIA

\section{Methods with Ultra-Short Base Line}

Carrying out the AUV mission with assistance of vessel gives operators another possibility to correct position of AUV under the sea surface. However the vessel have to be equipped with acoustic positioning system providing solutions to distribute corrections via acoustic link to the vehicle. These types of positioning techniques belong to group of systems with ultra-short base line. The functional principle is based on measurements of time required for the acoustic signal to travel between the transponder on the vehicle and transducer implemented on the vessel. 


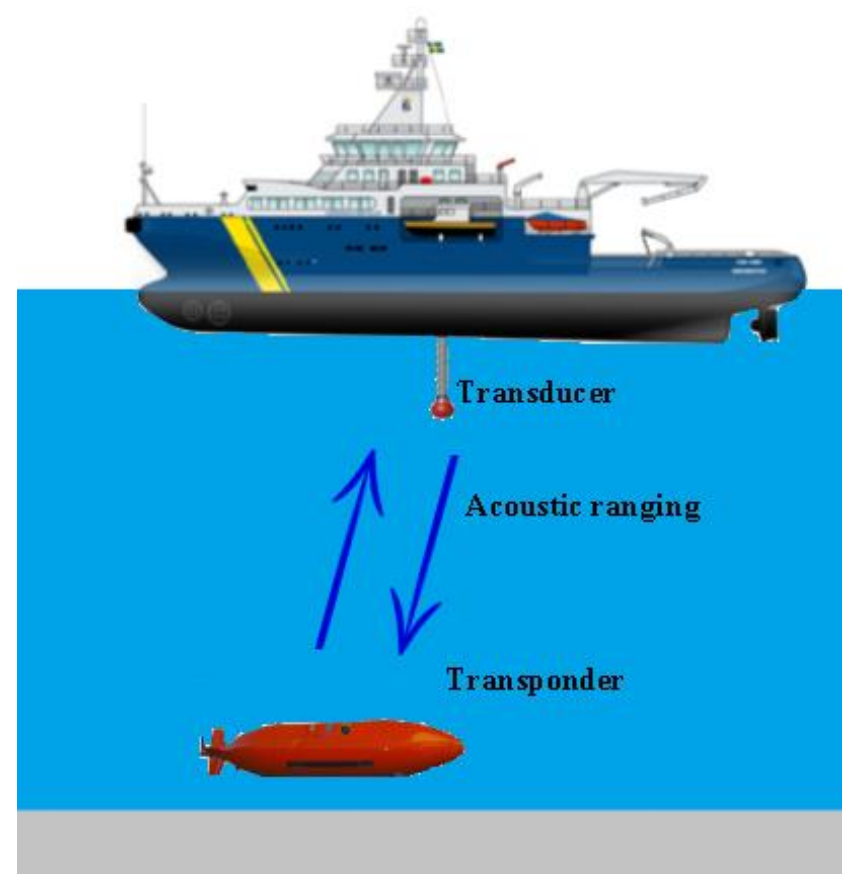

Fig. 5. Calibration of vehicle position with USBL system

Time determine the distance between the AUV and vessel. The bearing is a result of calculations based on changes of acoustic signals phases received by elements of vessel transducer. An example of that solution might be the High Precision Acoustic Positioning system (HiPAP), where the transducer head consist of 31, 46 or even 241 elements [5]. Using the system with that configuration operators needs to be aware that sending to the vehicle incorrect position can lead to unstable and unexpected movement. Fig. 6 shows a map with vehicle track pattern. The green lines shows the mission plan generated by operator and the white lines visualize real vehicle track during the mission. Difference between green and white lines represent effects of sending to the AUV wrong position. In that case vehicle decides that position send from the vessel is more accurate than calculated by INS and recalculates the mission plan.

Another type of solution concerning the systems with ultra-short base line is Underwater Transponder Positioning (UTP). These method of establishing position is based on the signals from the reference transponder placed on a sea bottom. After placing on the bottom, calibration of transponder position has to be carried out. For that reason the USBL system implemented on the vessel, for example HiPAP system, can be used. An accurate position of transponder is a result of range and 
bearing measurements. Using HiPAP system and assuming a GPS north and east accuracy of $0.4 \mathrm{~m}(1 \sigma)$, the Earth-fixed location of the transponder can be determined to within 0.6, 1, 2 and $3 \mathrm{~m}$ at 500, 1000, 2000 and $3000 \mathrm{~m}$ depth, respectively. As the depth decreases the GPS accuracy becomes the dominant source in the error budget. An accurate position of reference transponder, needs to be saved in vehicle memory before the mission start. When running UTP with the AUV, the interrogation of the transponder may be started and stopped both manually and automatically. In auto mode the interrogation is initiated when AUV operates inside the transponder range.

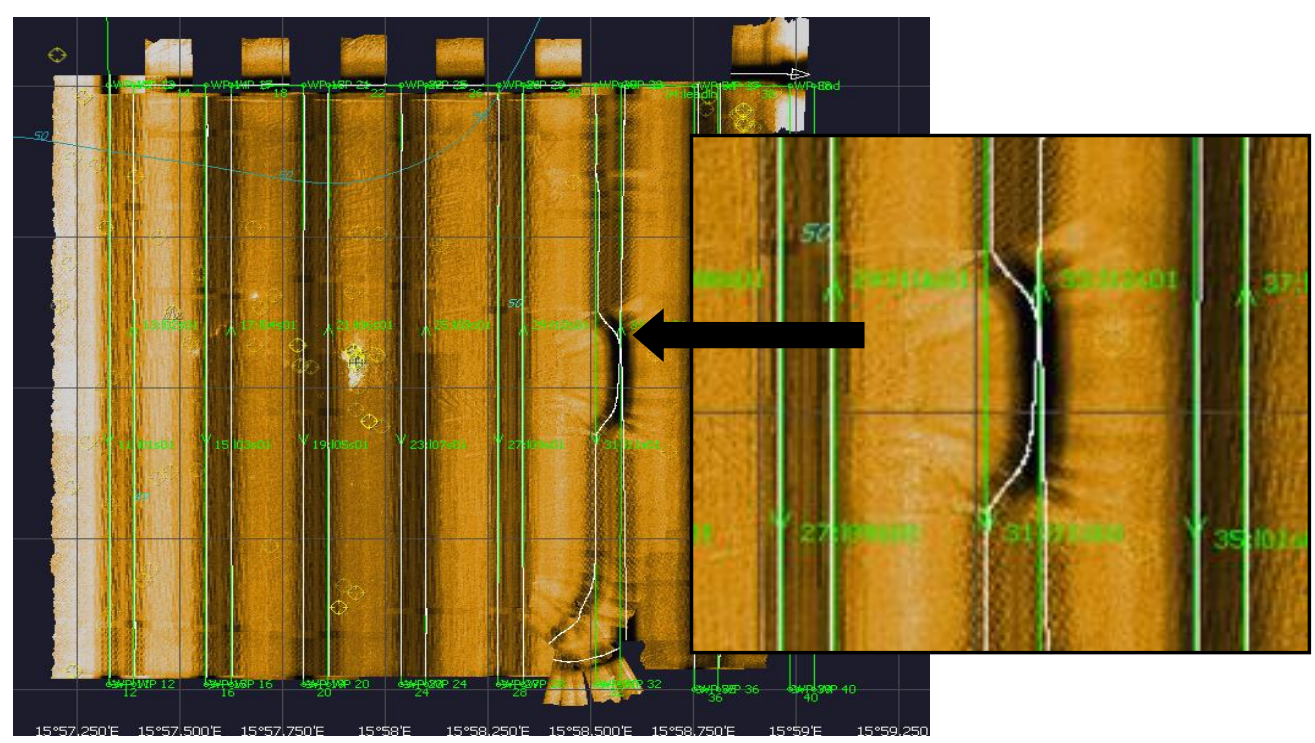

Fig. 6. Error occurred as a result of sending wrong geographical position to the vehicle via acoustic link

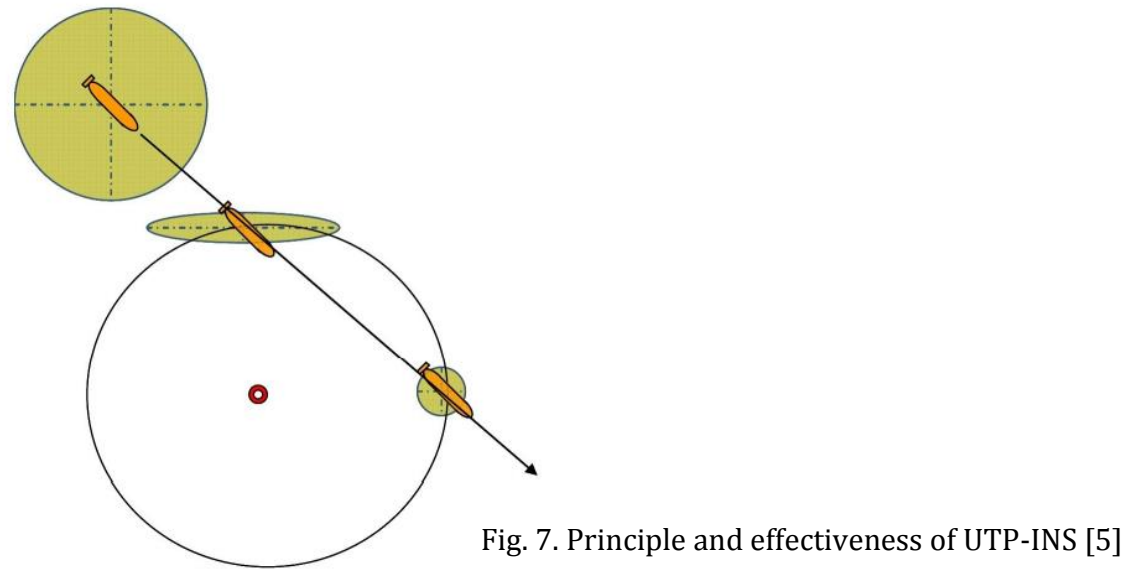

1 (216) 2019 


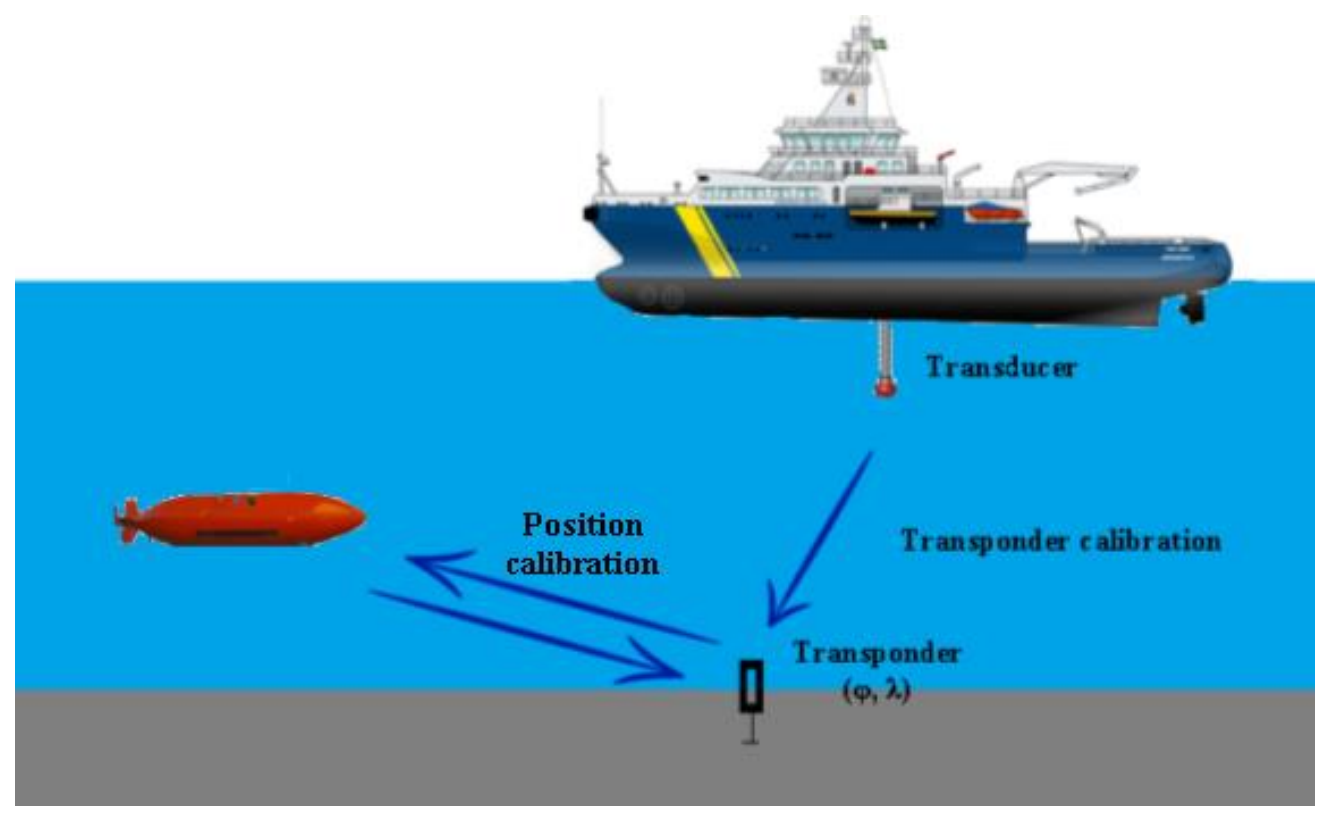

Fig. 8. Calibrating of vehicle position based on information from reference transponder

Tab. 1. Comparison of HiPAP USBL and UTP system accuracy

\begin{tabular}{|c|c|l|}
\hline System & Precision & \multicolumn{1}{c|}{ Rate } \\
\hline HiPAP USBL & $<20 \mathrm{~cm}, 0.12 \mathrm{deg}$. & $\begin{array}{l}\text { Depend on the slant range. While submerged, } \\
\text { the AUV receives position updates at about } \\
1 / 30 \mathrm{~Hz} \text {, from the surface via an acoustic link }\end{array}$ \\
\hline UTP & $<10 \mathrm{~cm}$ & $\begin{array}{l}\text { Depends on the range from the AUV } \\
\text { to the transponder. Usually }>1 / 2 \mathrm{~Hz}\end{array}$ \\
\hline
\end{tabular}

\section{Methods with Long Base Line and combined methods}

Long Baseline systems derive a position with respect to a seafloor deployed array of transponders. The position is generated using three or more time of flight ranges to/from the seafloor stations. A LBL system can work in responder or transponder mode. Any range/range position derived from a LBL system is with respect to relative or absolute seafloor coordinates. As such a LBL system does not require a Vertical Reference Unit (VRU) or gyroscope [7].

Combined methods consist of not less than two methods listed above, used in a single vehicle mission for example USBL/LBL, UTP/USBL, USBL/GPS. These methods gives possibility to reach higher accuracy and effectiveness of AUV positioning, and also provide redundancy in case of system elements failure. 
Methods of autonomous underwater vehicles positioning

Tab. 2. Characteristics of hydroacoustic navigational systems [6]

\begin{tabular}{|c|c|c|c|c|c|c|}
\hline Type & Producer & $\begin{array}{c}\text { Frequency } \\
{[\mathrm{kHz}]}\end{array}$ & Pulse type & $\begin{array}{c}\text { Number } \\
\text { of tracking } \\
\text { transponders }\end{array}$ & $\begin{array}{c}\text { Range } \\
\text { [m] }\end{array}$ & $\begin{array}{c}\text { Accuracy } \\
{[\mathrm{m}]}\end{array}$ \\
\hline \multicolumn{7}{|c|}{ Long Base Line Systems } \\
\hline ATNAV II & EG\&G & $7.5-15$ & Conventional & 1 & 8000 & $2-3$ \\
\hline RS 906 & $\begin{array}{l}\text { Honeywell/ } \\
\text { Nautronix }\end{array}$ & & Conventional & 1 & 2000 & 1 \\
\hline 408 & $\begin{array}{l}\text { Simrad/ } \\
\text { Kongsberg }\end{array}$ & $\begin{array}{l}12 \\
30\end{array}$ & Conventional & 16 & $\begin{array}{l}8000 \\
2000\end{array}$ & 1 \\
\hline LRPLBL & LinkQuest & $7.5-12$ & $\begin{array}{l}\text { Broadband } \\
\text { spread } \\
\text { spectrum }\end{array}$ & & 7000 & $0.005-0.05$ \\
\hline Sharps & Marquest & 300 & $\begin{array}{l}\text { Broadband } \\
\text { spread } \\
\text { spectrum }\end{array}$ & 2 & 100 & 0.02 \\
\hline \multicolumn{7}{|c|}{ Ultra-Short Base Line Systems } \\
\hline $\begin{array}{l}4068 \\
\text { NAVTRACK V }\end{array}$ & $\begin{array}{l}\text { EDO } \\
\text { Western }\end{array}$ & $\begin{array}{l}\text { Interrogation: } \\
22-28 \\
\text { Response: } 30\end{array}$ & Conventional & 5 & 2500 & $\begin{array}{l}1 \%-3 \% \\
\text { of range }\end{array}$ \\
\hline ATS & Nautronix & $15-18$ & Chirp & $2-8$ & & $\begin{array}{l}0.25 \% \\
\text { of range }\end{array}$ \\
\hline HiPAP & $\begin{array}{l}\text { Simrad/ } \\
\text { Kongsberg }\end{array}$ & $\begin{array}{l}\text { Interrogation: } \\
20-26 \\
\text { Response: } \\
26-36\end{array}$ & Conventional & 3 & 4000 & $\begin{array}{l}1-2 \% \\
\text { of range }\end{array}$ \\
\hline HPR 400 & $\begin{array}{l}\text { Simrad/ } \\
\text { Kongsberg }\end{array}$ & $\begin{array}{l}\text { Interrogation: } \\
20-40 \\
\text { Response: } \\
26-38\end{array}$ & Conventional & 16 & 2500 & $\begin{array}{l}1-3 \% \\
\text { of range }\end{array}$ \\
\hline Trackpoint II & ORE & $\begin{array}{l}\text { Interrogation: } \\
4-30 \\
\text { Response: } \\
22-30\end{array}$ & Conventional & 6 & 2500 & $\begin{array}{l}0.25 \% \\
\text { of range }\end{array}$ \\
\hline LXT & ORE & $\begin{array}{l}\text { Interrogation: } \\
17 \text { and } 19 \\
\text { Response: } \\
22-30\end{array}$ & Conventional & 2 & 2500 & 1 \\
\hline $\begin{array}{l}\text { TrackLink } \\
1500 \text { HA }\end{array}$ & Link Quest & $31-43$ & $\begin{array}{l}\text { Broadband } \\
\text { spread } \\
\text { spectrum }\end{array}$ & 6 & 1500 & 0.2 \\
\hline
\end{tabular}

\section{ANALYSIS OF AUV POSITIONING SYSTEM ACCURACY}

Taking into account that all listed above methods of AUV positioning are burdened with accuracy errors it is highly recommended to verify real value of that

1 (216) 2019 
errors. Some systems like AUV HUGIN has possibility to display uncertainty of navigational position after the mission, based on the vehicle logs. However in that case we are speaking only about the uncertainty of vehicle position, not about precise location. It is possible to estimate the real error ellipse value by comparing the positions of reference object on the sonar data, acquired during the mission. Reference object should be easily stand out from the background and have well known, accurate position. One of the method to obtain this position is to equip an object with transponder. After the mission, analyses of collected sonar data gives possibility to estimate system accuracy and capabilities. Fig. 9 shows multiple detections of one reference object carried out during the mission. Drifting positions of reference object on sonar data shows the AUVs positioning system accuracy. In that case the final position error is equal $11 \mathrm{~m}$.

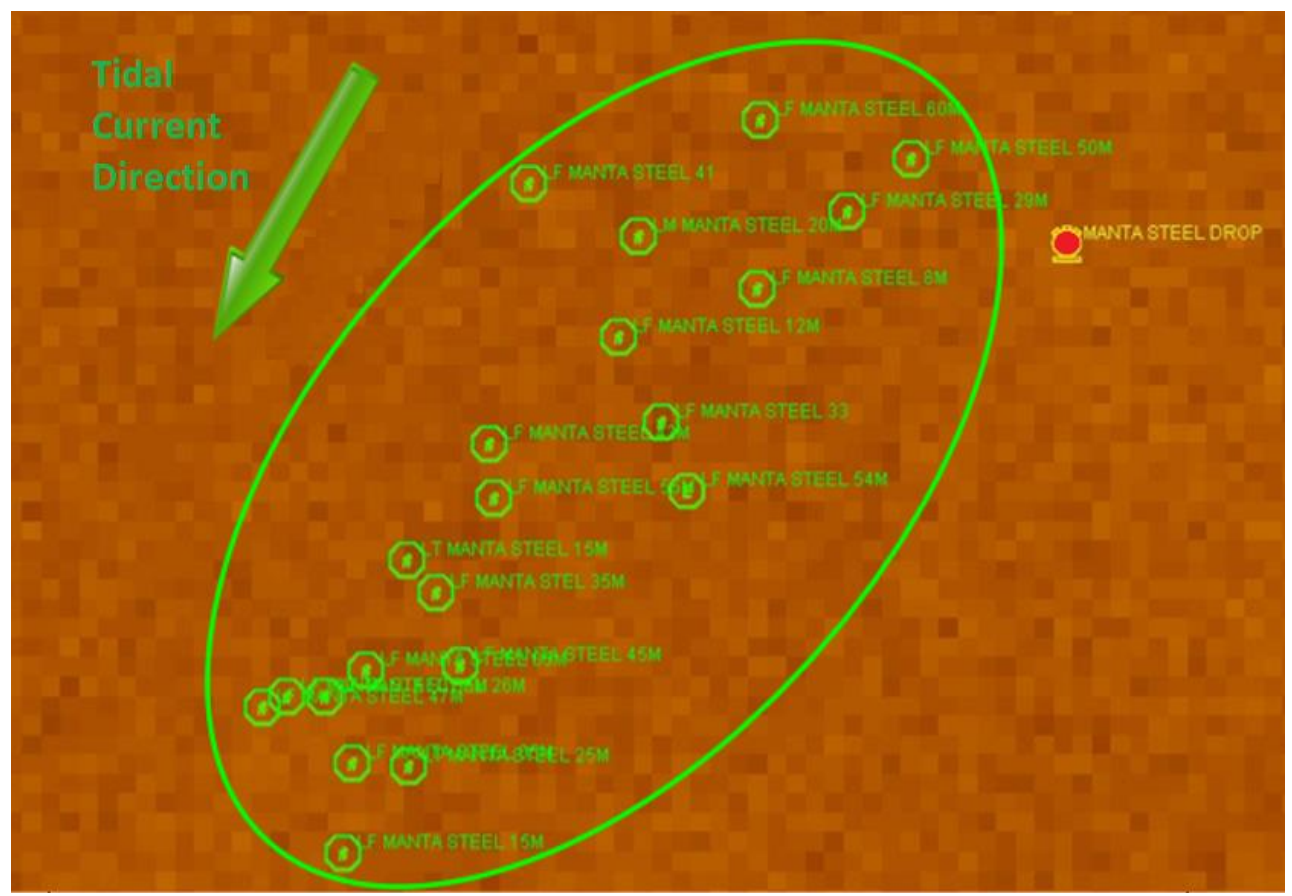

Fig. 9. Verification of positioning system accuracy

Comparison of navigation uncertainty from the logs with the drifting positions of reference object on sonar data shows that increasing uncertainty is not always connected with higher error of actual vehicle position. 
Tab. 3. Comparison of presented positioning methods

\begin{tabular}{|c|c|c|}
\hline POSITIONING METHOD & Range [m] & Position accuracy \\
\hline INS with DVL & - & $0.1 \%$ of travelled distance \\
\hline $\begin{array}{c}\text { USBL (Ultra Short Base Line), e.g. } \\
\text { HiPAP system }\end{array}$ & $2500-4000$ & $<20 \mathrm{~cm}, 0.12 \mathrm{deg}$. \\
\hline $\begin{array}{c}\text { Upgrading position } \\
\text { with GPS data }\end{array}$ & world wide & $\begin{array}{c}\text { Standard: } 1-3 \mathrm{~m} \\
\text { Real time kinematic GPS: }<10 \mathrm{~cm}\end{array}$ \\
\hline $\begin{array}{c}\text { UTP (Underwater Transponder } \\
\text { Positioning) }\end{array}$ & up to 4000 & $<10 \mathrm{~cm}$ \\
\hline LBL (Long Base Line) & $100-8000$ & approx. $1 \mathrm{~m}$ \\
\hline
\end{tabular}

\section{CONCLUSIONS}

Selection of proper method, taking into account environmental conditions and mission purpose, is crucial for the effectiveness of whole effort in the area. During the operations focused on detection, classification and identification of small objects (e.g. $1 \mathrm{~m}$ x $1 \mathrm{~m}$ ), especially objects causing possible threat, high accuracy of collected data is the basis for carrying out further disposal tasks. Precise localization is very important also in the area where many small object are placed on very small area. In that case high accuracy of geographic position increase Remotely Operated Vehicle (ROV) operators and divers confidence that they are working with an objects which they expected. What is more, in the areas with poor water visibility (e.g. Baltic Sea) it is impossible to carry out identification process with optical sensors implemented on AUV without good position data quality.

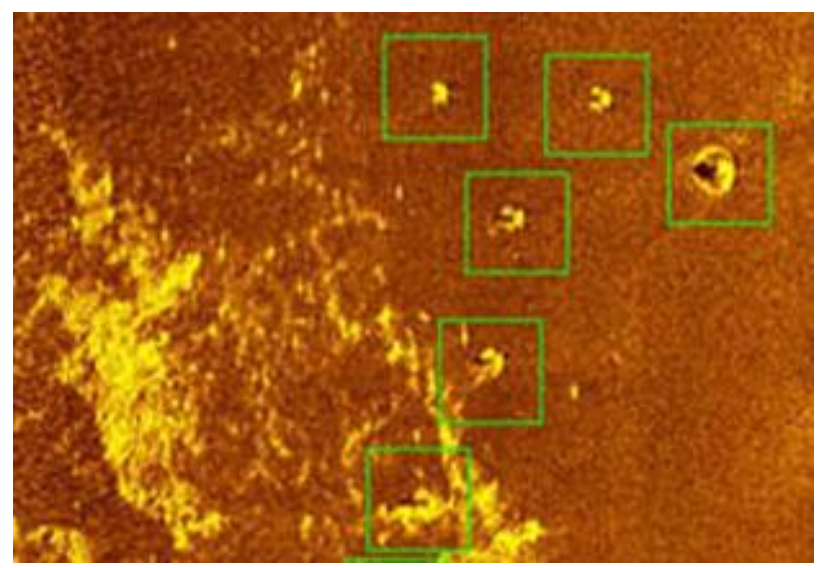

Fig. 10. Group of objects detected on small area

1 (216) 2019 
Depending on the type of AUV mission operators needs to be aware of possibilities and restrictions connected with positioning method which they choose, mainly concerning environmental conditions and safety aspects. Table presented below include main restrictions connected with above mentioned techniques of establishing AUV position.

Tab. 4. Restrictions of positioning methods

\begin{tabular}{|c|c|}
\hline POSITIONING METHOD & RESTRICTIONS \\
\hline INS with DVL & Degradation of position accuracy with the mission time \\
\hline $\begin{array}{l}\text { USBL (Ultra Short Base } \\
\text { Line), e.g. HiPAP system }\end{array}$ & $\begin{array}{l}\text { Range restricted by actual propagation of acoustic wave in } \\
\text { the water. AUV needs to keep stable acoustic link with vessel }\end{array}$ \\
\hline $\begin{array}{l}\text { Upgrading position } \\
\text { with GPS data }\end{array}$ & $\begin{array}{l}\text { Operation require resurfacing vehicle and keeping that } \\
\text { position for few minutes. Especially unsafety in area with high } \\
\text { traffic density and not effective during the mission on deep } \\
\text { waters }\end{array}$ \\
\hline $\begin{array}{c}\text { UTP (Underwater } \\
\text { Transponder Positioning) }\end{array}$ & $\begin{array}{l}\text { Operation require deploying reference transponder on the sea } \\
\text { bottom with accurate well known position. Range restricted by } \\
\text { actual propagation of acoustic wave in the water }\end{array}$ \\
\hline LBL (Long Base Line) & $\begin{array}{l}\text { Operation require deploying reference transponders on the sea } \\
\text { bottom with accurate well known positions. Range restricted } \\
\text { by actual propagation of acoustic wave in the water - distance } \\
\text { between transponders needs to be within the acoustic signal } \\
\text { range }\end{array}$ \\
\hline
\end{tabular}

\section{REFERENCES}

[1] Bray D., DP Operator's Handbook, Nautical Institute, London 2015.

[2] Hegrenaes Ø., Gade K., Hagen O. K., Hagen P. E., Underwater Transponder Positioning and Navigation of Autonomous Underwater Vehicles, IEEE Oceans Conference and Exhibition, Biloxi 2009.

[3] HELCOM: Baltic Marine Environment Protection Commission, [online], http://www.helcom.fi/ PublishingImages/baltic-sea-trends/hazardous-substances/sea-dumped-chemical-munitions/ Chemical_Munition_Dumpsites_Southern\%20Baltic\%20hires.gif [access 12.02.2019].

[4] Hiller T. M., Positioning Small AUVs for Deeper Water Surveys Using Inverted USBL, Presented at Hydro12, Rotterdam, November 2012, [online], https://www.hydroconferences.org/ documents/hydroconferences/downloads/4/oral_6.3_(tom_hiller).pdf [access 12.02.2019].

[5] Kongsberg Maritime, [online], https://www.km.kongsberg.com/ks/web/nokbg0240.nsf/ AllWeb/57C3D6E74A144E4BC1257F090034AE8A?OpenDocument [access 12.02.2019].

[6] Rowiński L., Pojazdy głębinowe, budowa i wyposażenie, WiB, Gdańsk 2008 [Deepwater vehicles constructions and equipment - available in Polish].

[7] Vickery K., Acoustic Positioning Systems a practical overview of current systems, Dynamic Positioning Conference, Houston 13-14 October 1998. 


\section{METODY POZYCJONOWANIA PODWODNYCH POJAZDÓW AUTONOMICZNYCH}

\section{STRESZCZENIE}

Artykuł stanowi wprowadzenie w tematykę pozycjonowania podwodnych systemów autonomicznych. Ujęto w nim charakterystykę obecnie wykorzystywanych metod pozycjonowania oraz wytyczne dla operatorów pojazdów autonomicznych w zakresie realizacji tego procesu.

Słowa kluczowe:

podwodne systemy autonomiczne, badania dna morskiego, metody pozycjonowania.

Article history

Received: 13.02.2019

Reviewed: 25.03.2019

Revised: 27.03.2019

Accepted: 28.03.2019

1 (216) 2019 